\title{
TIDAL ASYMMETRY IN MANGROVE CREEKS
}

\author{
Vo Luong Hong Phuoc, Le Tran Duy Phuc
}

University of Science, VNU-HCMC

ABSTRACT: A simple analytical model for flow in the creeks is formulated, built up and applied in the real conditions in Nang Hai creek, Can Gio mangrove Biosphere Reserve (Ho Chi Minh city).Observed data of current speed and water level in the creek in the year of 2005 were used to find the friction coefficients in the mangrove swamp and to apply in the model. Results from calculated modeling show obviously the tidal asymmetry in mangrove creek. The peaks of current speed at flood and ebb tides are not equal as the swamp is inundated. The friction coefficients have the great influence in the tidal asymmetry. The friction coefficient in the creek can change remarkably the current speed in the creek, inducing the changes of the current speed peaks. The friction coefficient in the swamp has much less influenced to the current speed in the creeks.

Keywords: tidal asymmetry, friction coefficient, mangrove creek, Can Gio mangrove Biosphere Reserve.

\section{INTRODUCTION}

A notable characteristic of the hydrodynamics of mangrove creeks is the asymmetry between the flood and ebb water velocity [1], [2], [3]. The aim of the study is to formulate and to build up a simple analytical model for flow in the creeks. The water level and friction coefficients are considered in the model of swamp-creek system. A simple analytical model for flow in the creeks is formulated. Swamp is characterized by a volume-water height relation and the creek is simply characterized by its average width, depth and length. The system is separated into two parts: the creek where inertial has to be taken into account, and the swamp where inertial effects can be neglected. In the swamp, the complex circulation through vegetation makes the flow friction dominated, and the momentum balance reduces to a balance between the water surface slope and the friction term [1].

\section{MODELLING}

The geometry is shown in Fig. 1. and the variables and parameters are introduced as follows [1]:

$h_{1}$ : characteristic height of water in the creek;

$h_{2}$ : characteristic height of water in the swamp;

$\mathrm{u}_{1}$ : characteristic current of water in the creek;

$\mathrm{u}_{2}$ : characteristic current of water in the swamp;

$\mathrm{V}_{1}$ : volume of water in the creek; 
$\mathrm{V}_{2}$ : volume of water in the swamp;

$\mathrm{H}$ : height of the water at the mouth of the creek;

B: width of the channel (averaged over the whole length);

$\mathrm{X}$ : length of the creek;

$\mathrm{X}_{\mathrm{s}}$ : length of the swamp (perpendicular to the channel);
$\mathrm{H}_{1}$ : depth of the swamp;

$\mathrm{r}_{1}$ : friction coefficient in the creek;

$\mathrm{r}_{2}$ : friction coefficient in the swamp;

$\frac{1}{C_{1}}$ : height/ volume of water ratio in the creek (between $\mathrm{h}_{1}$ and $\mathrm{V}_{1}$ )

$\frac{1}{C_{2}}$ : height/ volume of water ratio in the swamp (between $\mathrm{h}_{2}$ and $\mathrm{V}_{2}$ )

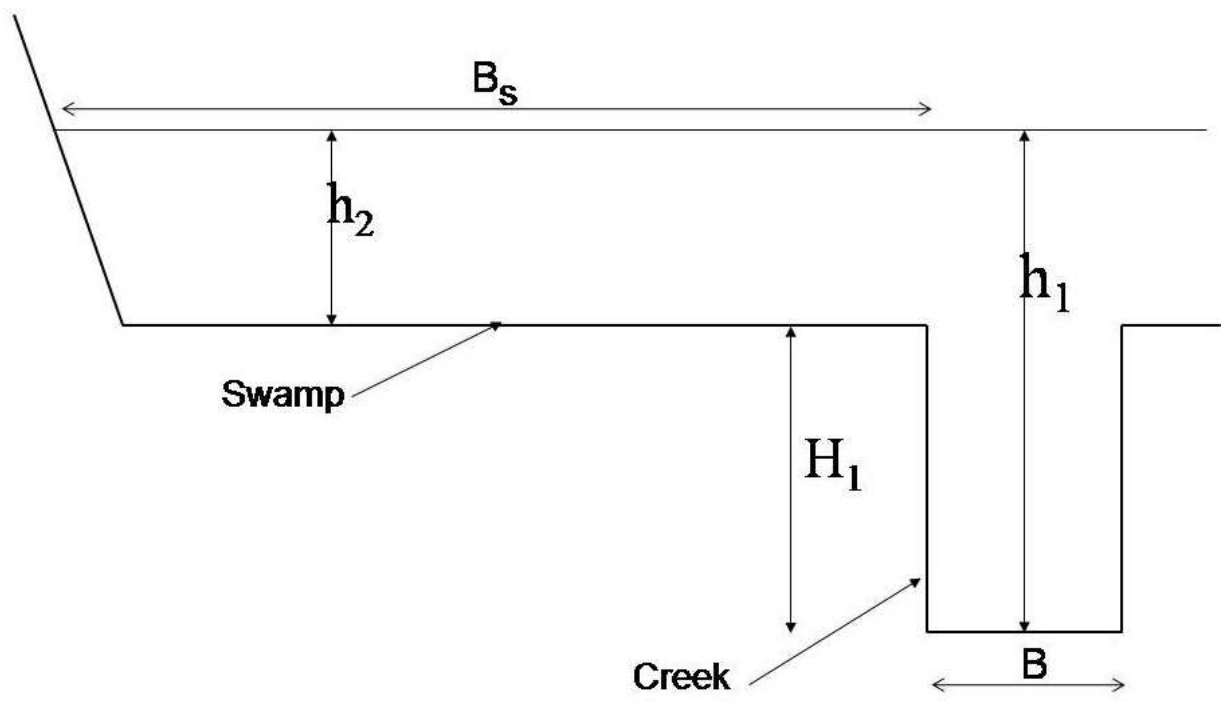

Fig 1. Cross section through creek and swamp

The governing equations in the creek and in the swamp can be written as: [1], [2]:

- In the creek:

$$
\begin{gathered}
\frac{\partial u_{1}}{\partial t}=-g \frac{\left(h_{1}-H\right)}{X}-r_{1} u_{1} \\
u_{1} B h_{1}=\frac{\partial V_{1}}{\partial t} \quad \text { when swamp is not }
\end{gathered}
$$

inundated

(2)

$$
u_{1} B h_{1}=\frac{\partial V_{1}}{\partial t}+\frac{\partial V_{2}}{\partial t} \text { when swamp is }
$$

inundated
- In the swamp:

$$
\begin{aligned}
& 0=-g \frac{\left[h_{2}-\left(H-H_{1}\right)\right]}{X_{s}}-r_{2} u_{2} \\
& u_{2} B_{s} h_{2}=\frac{\partial V_{2}}{\partial t}
\end{aligned}
$$

It is assumed that the variations in $h_{1}$ with time are small compared to those of $u_{1}$. With some calculations, we obtain:

When the swamp is not inundated: 


$$
\frac{X}{g B h_{1}} \frac{\partial^{2} V_{1}}{\partial t^{2}}+\frac{r_{1} X}{g B h_{1}} \frac{\partial V_{1}}{\partial t}+\frac{V_{1}}{C_{1}}=H
$$

When the swamp is inundated:

$$
\begin{gathered}
\frac{X}{g B h_{1}} \frac{\partial^{2}\left(V_{1}+V_{2}\right)}{\partial t^{2}}+\frac{r_{1} X}{g B h_{1}} \frac{\partial\left(V_{1}+V_{2}\right)}{\partial t}+\frac{V_{1}}{C_{1}}=H \\
\frac{r_{2} X_{S}}{g B_{s} h_{2}} \frac{\partial V_{2}}{\partial t}+\frac{V_{2}}{C_{2}}=H-H_{1}
\end{gathered}
$$

The following parameters are introduced:

$$
\begin{gathered}
L=\frac{X}{g E h_{1}} \\
R_{1}=\frac{r_{1} X}{g B h_{1}} \\
R_{2}=\frac{T_{2} X_{s}}{g R_{s} h_{2}}
\end{gathered}
$$

The equation of the motion in the creek can be written in the following terms:

When the swamp is not inundated:

$$
\begin{gathered}
\frac{X}{g B h_{1}} \frac{\partial^{2} V_{1}}{\partial t^{2}}+\frac{r_{1} X}{g B h_{1}} \frac{\partial V_{1}}{\partial t}+\frac{V_{1}}{C_{1}}=H \\
L \frac{\partial^{2} V_{1}}{\partial t^{2}}+\quad R_{1} \frac{\partial V_{1}}{\partial t}+\frac{V_{1}}{C_{1}}=H
\end{gathered}
$$

When the swamp is inundated:

$$
L \frac{\partial^{2}\left(V_{1}+V_{2}\right)}{\partial t^{2}}+R_{1} \frac{\partial\left(V_{1}+V_{2}\right)}{\partial t}+\frac{V_{1}}{c_{1}}=I I
$$

The equation of the motion in the swamp can be written in the following terms:

$$
R_{2} \frac{\partial V_{2}}{\partial t}+\frac{V_{2}}{C_{2}}=H-H_{1}
$$

From the equations (2)-(3), (5) and (9)(11), the water volumes $\mathrm{V}_{1}$ (in the creek), $\mathrm{V}_{2}$ (in the swamp) and current velocities $\mathrm{u}_{1}, \mathrm{u}_{2}$ are solved by numerical methods.

\section{applications}

Model is built up and applied in the real conditions in Nang Hai creek, Can Gio (Ho Chi Minh city) (Fig.2.) Nang Hai site $\left(10^{0} 23.427 \mathrm{~N}\right.$, $106^{0} 52.761 \mathrm{E}$ ) is about $2.0 \mathrm{~km}$ distant from the estuary of the Dong Tranh river, which with a length of $67.50 \mathrm{~km}$ is the longest of the main rivers in Can Gio Mangrove Biosphere Reserve [4] (Fig.2.). Nang Hai is a complicated site with many surrounding creeks and mixed-type mangroves. Nang Hai creek is considered as the largest creek in Nang Hai site (Fig.3.). Based on the observed measurements at the studied site [5], [6], it is assumed that the length of the creek is $2.5 \mathrm{~km}$ and the width is $20 \mathrm{~m}$. The characteristic of water level is $2.5 \mathrm{~m}$ in the creek and $0.2 \mathrm{~m}$ in the swamp. The height and the length in the swamp are $2.3 \mathrm{~m}$ and 700 $\mathrm{m}$, respectively.

The model used the input data measured and observed in one week from $30^{\text {th }}$ January, 2005 to $7^{\text {th }}$ February, 2005 at Nang Hai creek. The data of water level was measured by wave gauge WG-730W (Valeport Co.) at the muddy flat of Nang Hai creek. The sampling frequency was $4 \mathrm{~Hz}$, and 2048 wave burst samples were recorded at 30 minute intervals. The data of current flows were measured every 30 minutes by the propeller MK11-2035 (General Oceanic). 

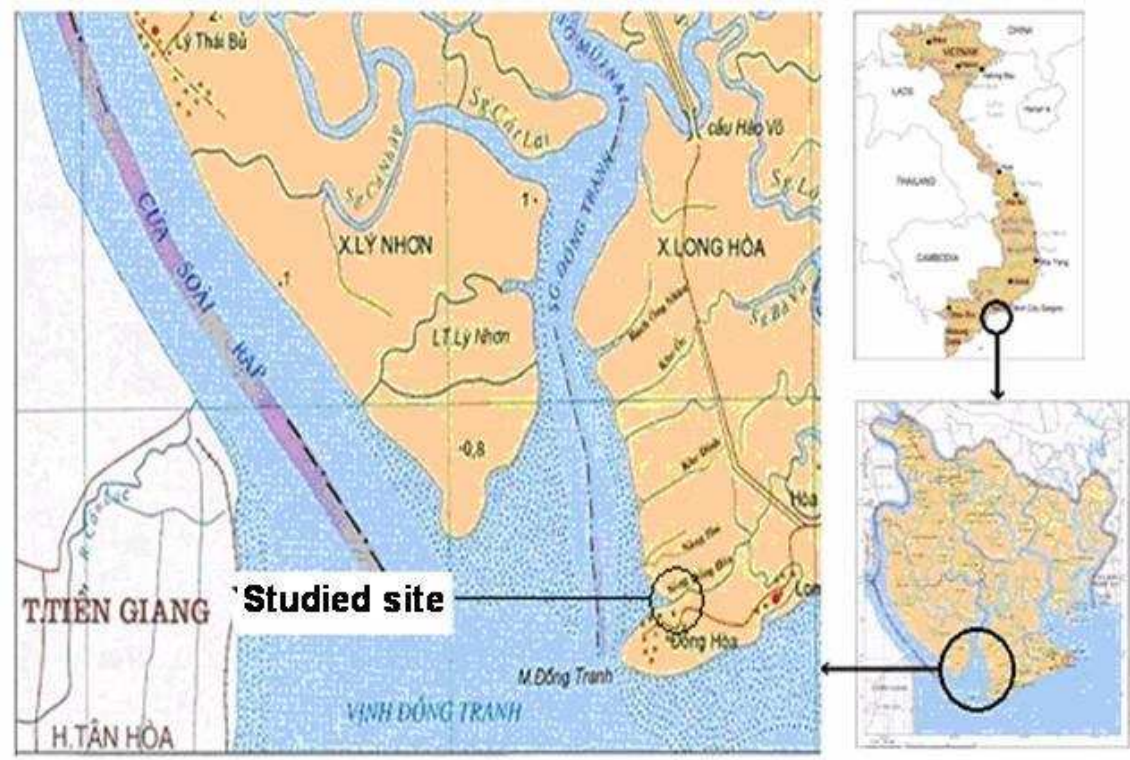

(a)

(c)

Fig.2. The location of the selected study site (a) in the South of Vietnam. (b) Can Gio mangrove Biosphere Reserve, Ho Chi Minh, Vietnam; (c) Nang Hai study site

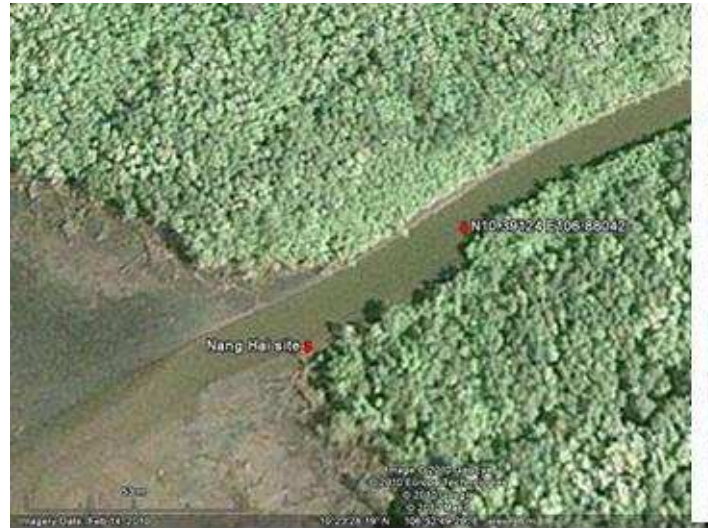

(a)

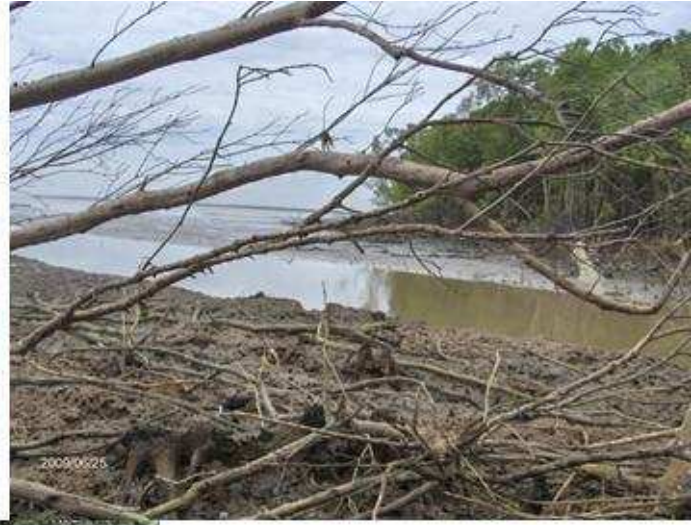

(b)

Fig.3. Nang Hai creek (a) from Google Map (b) in ebb tide on 25th June, 2009

\section{RESULTS}

From the simulated model and the characteristic parameters in Nang Hai creek and its swamp, compared with the observed data of current velocities in the creek, we could predict the current flows with the suitable friction coefficients. The different friction coefficients with order of $10^{-4}, 10^{-3}$ and $10^{-2}$ were chosen. Obviously when the friction coefficient is large (order of $10^{-2}$ ), the velocity gets very small. The smaller the friction coefficient is (order of $10^{-4}, 10^{-3}$ ), the higher the velocity gets. Results show that the 
calculated velocity gave the most suitable data compared with the measured velocity when the friction coefficient with the order of $10^{-4}$ was chosen. The best-fit friction coefficient in the creek was 0.0026. (Fig. 4.). The friction coefficients have the great influence in the tidal asymmetry. The friction coefficient in the creek can change remarkably the current speed in the creek, inducing the changes of the current speed peak. The friction coefficient in the swamp has much less influenced to the current speed in the creeks.

Figure 4 shows the model output that best agrees with the experimental data for current speed in Nang Hai. It also shows that the swamp was inundated almost for flood water. The current peaks at high tide and at low tides were different in the tidal cycles. The maximum current velocity reached to about $0.65 \mathrm{~m} / \mathrm{s}$. It is obviously seen that in a tidal cycle, the tidal current speed depended on the tidal slope. The higher tidal slope got, the higher current velocity peak was and vice versa.

Results from calculated modeling show obviously the tidal asymmetry in mangrove creek. Almost in the tidal cycles, there were two current peaks for flood tides and two or three current peaks for ebb tides. However, there were always a current peak at flow tides as the water level reached to the height of swamp with $2.3 \mathrm{~m}$ due to amount of water flowed from the creek to the swamp.

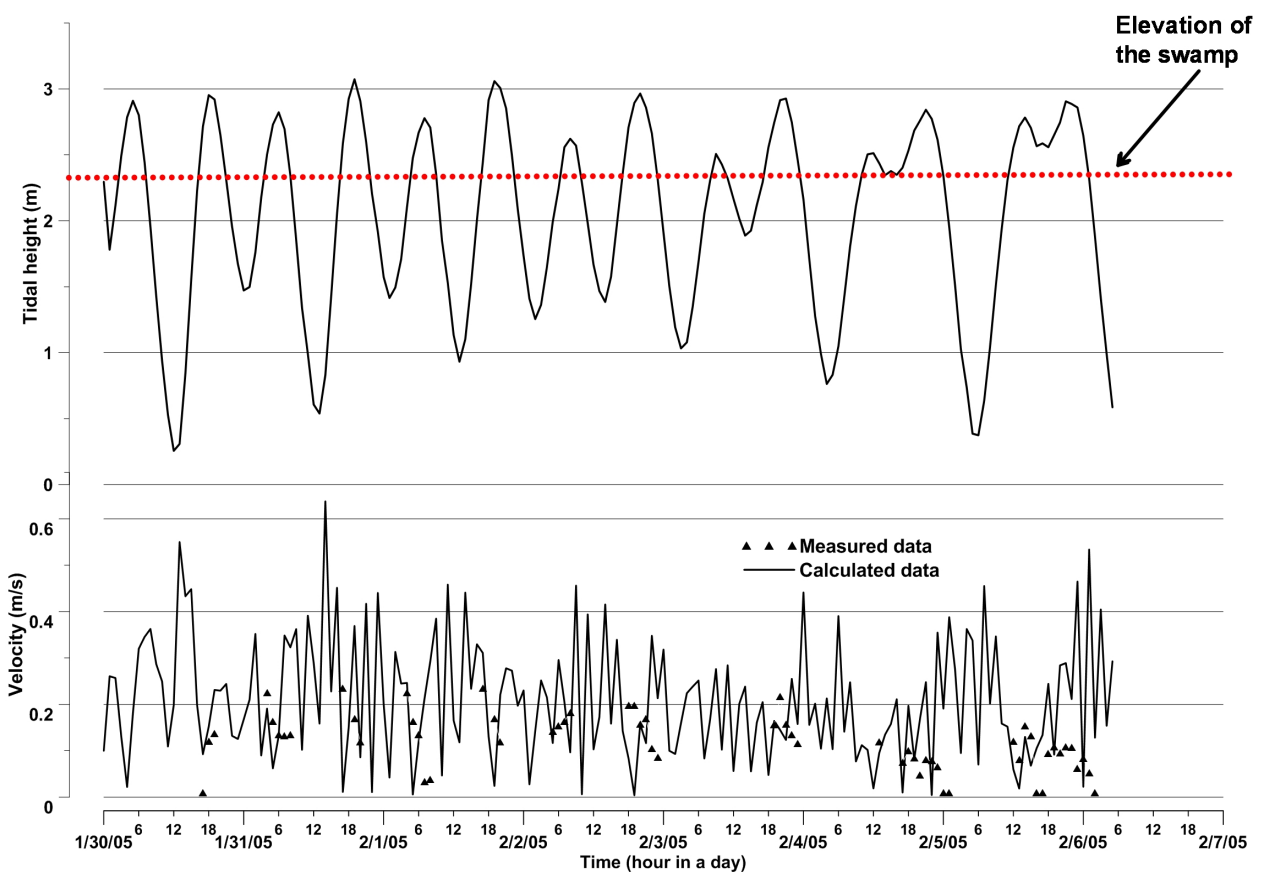

Fig.4. Current speed in the Nang Hai creek

On $4^{\text {th }}$ and $5^{\text {th }}$ of February 2005, the swamp was inundated for the high ebb tide. As a result, the current velocity was relatively small. In these two days, the tidal slopes were rather 
high and the tidal cycle was different from the rest of the days, therefore the velocity peaks for ebb and flow tides were different from the rest of the days. There were three current velocity peaks for the first flood tide of the day and three current velocity peaks for second ebb tide in the day.
The tidal asymmetry in mangrove creek is obviously proved by the velocity peaks for flood and ebb tides However, from the modeling application in Nang Hai creek, we could not withdraw the exact number of current velocity peaks for flood and ebb tides. The research on the tidal asymmetry in the mangrove creek is required for further study.

\title{
CONCLUSIONS
}

\section{TÍNH BẤT ĐỐI XỬNG CỦA THỦY TRIỀU TRONG KÊNH RẠCH CÓ RỪ NG ẬP MặN}

\author{
Võ Lương Hồng Phước, Lê Trần Duy Phúc \\ Trường Đại học Khoa học Tự nhiên, ĐHQG-HCM
}

TÓM TÄT: Mô hình động lục học thủy triều giải tích đơn giản cho dòng chảy trong kênh rạch đurợc thiết lập và xây dưng; sau đó được áp dụng giả định với điều kiện thực tại con rạch Nàng Hai, khu dụ trũ sinh quyển rùng ngập mặn Cần Giờ (Thành Phố Hồ Chí Minh). Số liệu quan trắc vận tốc dòng và dao động mưc nuớc tại con rạch vào năm 2005 được sử dụng để tìm hệ số ma sát trong con rạch và trong đầm và để áp dụng tính tóan trong mô hình. Kết quả tù mô hình tính toán cho thấy rõ được tính bất đối xứng của thủy triều trong con rạch. Đỉnh vận tốc lúc triều lên và lúc triều rút không bằng nhau khi nuơớc ngập đầm lầy. Hệ số ma sát cũng ảnh huởng rất lớn đến tính bất đối xứng của thủy triều này. Hệ số ma sát trong con rạch làm thay đổi đáng kể đến vận tốc dòng trong con rạch, dẫn đến sụ biến đổi lớn của các đỉnh vận tốc. Hệ số ma sát trong đầm lầy không ảnh huởng nhiều đến vận tốc dòng trong rach.

Tù khóa: tính bất đối xứng thủy triều, hệ số ma sát, kênh rạch trong rù̀ng ngập mặn, khu dụ trũ sinh quyển rù̀ng ngập mặn Cần Giò.

\section{REFERENCES} asymmetry in creeks surrounded by saltflats and mangroves with small 
swamp slopes. Wetlands Ecology and

Management, 8, 223 - 231 (2000).

[2]. Mazda, Y., Kanazawa, N. and Wolanski, E. Tidal asymmetry in mangrove creeks. Hydrobiologia 295, $51-58$ (1995).

[3]. Mazda, Y., Wonlanski, E., Ridd, P. The role of physical processes in mangrove environments. TERRAPUB. Japan (2007).

[4]. Tuan L. D, Oanh K T. T., Thanh C. V., Quy N. D. Can Gio mangrove biosphere reserve. Agric. Publ.,Hanoi (2002).

[5]. Vo Luong, H.P, Massel, S.R. Energy dissipation in non-uniform mangrove forests of arbitrary depth. Journal of Marine Systems 74, 603-622 (2008).

[6]. Vo Luong Hong Phuoc, Dang Truong An. The role of mangrove forests in coastal zone management. Journal of Sciences of the Earth, 32, 1, 87-90 (2010) (in Vietnamese). 